\title{
Immunologic Parameters in Childhood Hodgkin's Disease II. T and B Lymphocytes in the Peripheral Blood of Normal Children and in the Spleen and Peripheral Blood of Children with Hodgkin's Disease*
}

\author{
M. DE SOUSA, † C. T. C. TAN, F. P. SIEGAL, D. A. FILIPPA, R. TAN, AND R. A. GOOD \\ Memorial Sloan-Kettering Cancer Center New York, New York, USA
}

\section{Summary}

A study of peripheral blood lymphocyte populations in 27 children with Hodgkin's disease (HD) and 13 age-matched control subjects is presented. The absolute numbers and percentages of $T$ and $B$ lymphocytes identified by their surface marker characteristics were determined. In addition, in 13 HD children the percentages of $T$ and $B$ lymphocytes were estimated in the spleens removed at staging laparotomy. No differences were observed between the total peripheral blood lymphocyte

- This project was aided by grants from the National Cancer Institute, CA08748 and CA-05826; American Cancer Society; Zelda R. Weintraub Foundation; Judith Harris Selig Foundation; Fund for Advanced Study of Cancer; Estes Lauder Foundation; and Special Projects Committee of Memorial Sloan-Kettering Cancer Center.

† Requests for reprints should be addressed to: M. de Sousa, M.D., Ph.D., Cell Ecology Laboratory, Memorial Sloan-Kettering Cancer Center, 1275 York Avenue, New York, NY 10021 counts of HD and control children, and we found no evidence of progressive lymphopenia with advancing stages of the disease. No decrease in the numbers of peripheral blood $T$ lymphocytes was seen in this group of HD children. In contrast, the proportions and absolute numbers of $B$ lymphocytes tended to be significantly lower in the children with HD than in the control subjects. In 9 of the 13 spleens studied high percentages of $T$ lymphocytes were seen; low percentages of $B$ lymphocytes were found in all spleens examined.

\section{Speculation}

The results are discussed in the light of the hypothesis that in HD an anomaly of the spleen environment is present at the early stages of the disease which results in sequestration of circulating $T$ lymphocytes, and that this anomaly is closely related to the basic pathogenesis of the disease. 
TABLE III

The existence of an abnormality of $T$ cell function in Hodgkin's disease is well documented in adult patients (19). The actual mechanism of development this abnormality, however, is not clear. Some authors have observed a low number of $T$ cells in the peripheral blood $(2,3,7)$, but this finding has not been confirmed $(5,6)$. Progressive overall absolute $T$ and $B$ lymphopenias have however been observed in adult patients with advancing stages of the disease $(5,6$,
$13)$. In a separate paper we reported the finding of an abnormality of the PHA 13). In a separate paper we reported the finding of an abnormality of the PHA responses of the peripheral blood lymphocytes in children with HD, irrespect (26). The simul taneous finding of norma I PHA responses of the splenic lympho-
cytes was interpreted as indicating that in HD there is an abnormality of $7 \mathrm{ym}-$ cytes was interpreted as indicating that in $\mathrm{HD}$ there is an abnormality of lym-
phocyte ecotaxis $(8,26)$. In the present paper we explore further the question of lymphocyte distribution in $H D$ by comparing the absolute numbers of $\mathrm{T}$ and $\mathrm{B}$ lymphocytes in the peripheral $H D$ by comparing the absolute numbers of $T$ and $B$ proportion of the two major iymphocyte populations in the spleen of the children with $H D$.

\section{MATERIALS AND METHODS}

\section{Peripheral Blood}

Control Group (Table I): A total of 13 normal children, 6 males and $7 \mathrm{fe}-$ males, were used as controls for this study. Details of their ages, ranging
from 5 to 16 years, and absolute lymphocyte counts are summarized in Table I. Characterization of the surface markers on the peripheral blood iymphocytes was Characterization of the surface markers on the peripheral blood lymphocytes was children.

\section{TABLE I}

AGE, SEX, AND TOTAL PERIPHERAL BLOOD LYMPHOCYTE COUNTS IN 13 CONTROL CHILDREN

\begin{tabular}{cccc} 
Control Child & Sex & Age & Total Lymphocyte Count $/ \mathrm{mm}^{3}$ \\
\hline Q.R. & M & 5 & 2975 \\
R.J. & M & 6 & 4515 \\
M.P. & M & 10 & 2490 \\
M.J. & M & 13 & 1775 \\
D.J. & M & 15 & 1914 \\
R.A. & M & 16 & 1452 \\
F.G. & F & 6 & 1224 \\
F.N. & F & 8 & 2146 \\
M.W. & F & 9 & 1320 \\
M.N. & F & 10 & 1392 \\
M.P. & F & 11 & 1440 \\
M.S. & F & 12 & 1911 \\
M.E. & F & 14 & 2580 \\
\hline & & Mean \pm 1 SD & $2087 \pm 907$
\end{tabular}

Hodgkin's Disease Group (Table II): A total of 63 children with HD, treatd at Memorial Sloan-Kettering Cancer Center between 1970 and 1976, were studled. There were 39 males and 24 females, between the ages of 4 years and 1 month and 16 years and 3 months. Total peripheral blood lymphocyte counts were performed at the time of staging laparotomy prior to treatment. The periphera blood lymphocyte subpopulations were characterized for surface markers in 27 patients, 15 males and 12 females. Detalls of stage of disease and histopathology of the children included in this study are summarized in Table II. The distribution of histological types differs between the two sexes. Twenty-one or iymphocyte depleted types were found. Of the 39 males studied, 8 (21\%) were or lymphocyte depleted types were found. of the 39 males studied, 8 (21\%) were
diagnosed as lymphocyte predominant (LP), 18 (46\%) were nodular sclerosing (NS), and $12(31 \%)$ were mixed cellularity.

TABLE II

DISTRIBUTION OF HD CHILOREN ACCORDING TO DISEASE STAGE AND HISTOLOGY

\begin{tabular}{|c|c|c|c|c|c|c|c|c|c|}
\hline \multirow[b]{2}{*}{ Stage } & \multicolumn{5}{|c|}{ Male } & \multicolumn{4}{|c|}{ Female } \\
\hline & $\mathrm{LP}$ & NS & $M C$ & LD & Total & NS & $M C$ & U & Total \\
\hline IA & $6(2) *$ & 4 & $2(2)$ & & $12(4)$ & $3(1)$ & & & $3(1)$ \\
\hline IB & & $2(1)$ & & & $2(1)$ & $2(1)$ & 1 & & $3(1)$ \\
\hline IIA & 1 & 2 & $1(1)$ & & $4(1)$ & $5(3)$ & 1 & & $6(3)$ \\
\hline II & & $3(1)$ & & & $3(1)$ & $4(3)$ & & $1(1)$ & $5(4)$ \\
\hline IIIA & 1 & $4(2)$ & $1(1)$ & & $6(3)$ & & & & 0 \\
\hline IIIB & & $3(2)$ & $4(3)$ & & $7(5)$ & $2(2)$ & & & $2(2)$ \\
\hline IVB & & & 4 & 1 & $5(0)$ & $5(1)$ & & & $5(1)$ \\
\hline Total & $8(2)$ & $18(6)$ & $12(7)$ & 1 & $39(15)$ & $21(11)$ & 2 & $1(1)$ & $24(12)$ \\
\hline
\end{tabular}

* () numbers had analysis of cell surface markers.

$L P=1$ ymphocyte predominant; $N S=$ nodular sclerosing; $M C=$ mixed cellularity; $L O=$ lymphocyte depleted; $U=$ unclassified.

\section{Spleen}

Control froup (Table III): No childhood control spleens were available during the course of this study. Control values used throughout the study have therefore been derived from the published control values of studies in which data is found in Table III.
CONTROL VALUES FOR LYMPHOCYTE SUBPOPULATIONS IN HUMAN SPLEENS

\begin{tabular}{lll} 
Author(s) & \multicolumn{1}{c}{ T } & Ig Bearing \\
\hline Greaves et a1, 1974 (16) & $33 \%$ & \\
Habeshaw and Stuart, $1974(18)$ & $36.5 \%$ & $45 \%$
\end{tabular}

Hodgkin's Disease Group (Table IV): Concomitant analysis of cell surface markers in the peripheral blood and spleen was done in nine children with $H D$ at the time of staging laparotomy. In an additional four patients the spleen, but not the blood, was studied at the time of staging laparotomy. Disease stage and sex of the children included in this portion of the study are summarized in Table IV.

TABLE IV

DISEASE STAGE OF 13 PATIENTS STUDIED FOR THE CONCOMITANT ANALYSIS OF LYMPHOCYTE MARKERS IN PERIPHERAL BLOOD AND SPLEEN

\begin{tabular}{cllc} 
Stage & Males & Females & Total \\
\hline IA & $2(1)^{\star}$ & 1 & 3 \\
IB & 2 & 0 & 2 \\
IIA & 0 & 1 & 1 \\
IIB & 1 & 0 & 1 \\
IIIA & $1(1)$ & 0 & 1 \\
IIIB & 2 & $2(1)$ & 4 \\
IVB & $1(1)$ & 0 & 2 \\
\hline Total & $9(3)$ & $4(1)$ & $13(4)$ \\
\hline * & () $=$ spleen only
\end{tabular}

\section{Preparation of Lymphoid Cell Suspensions}

Suspensions of lymphoid cells were obtained from uninvolved portions of the spleen by teasing pieces gently into RPMI 1640 under sterile conditions. After preparing the suspension the spleen cells were layered on a FicollHypaque density gradient (d:1.077). Peripheral blood lymphocytes were also obtained by separating $25 \mathrm{ml}$ of heparinized blood (diluted in Hank's Balanced Salt Solution (HBSS, $1: 1$ ), on a Ficoll-Hypaque density gradient. Cells removed from the interface were washed three times in HBSS and then cell viability was checked by trypan blue exclusion. Only cell suspensions of more than 95\% viability were analysed.

The suspensions were then divided into two separate samples, one to be used for rosette formation and membrane immunofluorescence, and the other for mitogen stimulation. To the former, 100n of $1 \%$ latex particles $10.86 \mathrm{n}$ diameter, Dow Chemical) were added, the cells were suspended in RPMI 1640 containing $20 \%$ tion with the latex particles, the cells were washed twice in RPMI.

\section{Cell Surface Markers}

Sheep erythrocyte rosettes were performed according to Bentwich et al (4); mouse erythrocyte rosettes by the method detailed by Gupta et al (17); (method detailed in 17 ) were detected by their ability to bind aggregated IgG ORh positive erythrocytes sensitized with IgG anti-Rh of the Ripley type (16).

RESULTS

\section{Lymphocyte Populations in Peripheral Blood of Normal and HD Children}

No differences were observed between the total lymphocyte counts of HD and control children. Moreover, we found no evidence of progressive lymphopenia with advancing stages of the disease. To the contrary, a slight increase in the total peripheral blood lymphocyte count was observed with progressively adranced dis to tal peripheral blood ymocyte count reflected a comparable increase in the total lymphocyte count ed patient with stage IV disease, who had a total T lymphocyte count of $3471 / \mathrm{mm}^{3}$, markediy higher than the mean control values.

In contrast, the proportion and absolute numbers of cells which bore surface Ig or were detected by the aggregate binding assay tended to be lower th $H D$ than the controls ( $P<0.0$ stage II, and $P<0.005$ for stage III, as compared to the controls), the cells detected as carrying Ig on their surface in the system used in the present cells, and cells which carry high affinity rece lg (mostly IgM or IgD), the B cells are functionally heterogeneous. Cells of the $B$ line were detected by two cells are functionally heterogeneous. Cells of the $B$ line were detected by two markers, the spontaneous mouse erythrocyte rosette and the presence of surface found with the mouse rosette tes in patients with their surface were depressed in stages I and II $(P<0.05)$ and in III, but not in the single case dessed in stages I an

On the other hand, the cells reactive with human IgG coated erythrocytes (the Ripley rosettes) did not show depression. Thus, most of the decrease in Ig bearing cells appears to be consequent to a specific decrease in $B$ cells

In HO patients there was a somewhat higher proportion of cells with no detectable markers than in normals. This was, however, not because of decreased proportions of $T$ cells, but because of decreased proportions of Ig-bearing cells, both $\mu$-bearing and those carrying other classes. The present findings were equally true whether expressed as absolute lymphocyte counts or as per- 
TABLE $V$

PERCENTAGE DISTRIBUTION OF LYMPHOCYTE SURFACE MARKERS IN NORMAL AND HD CHILDREN

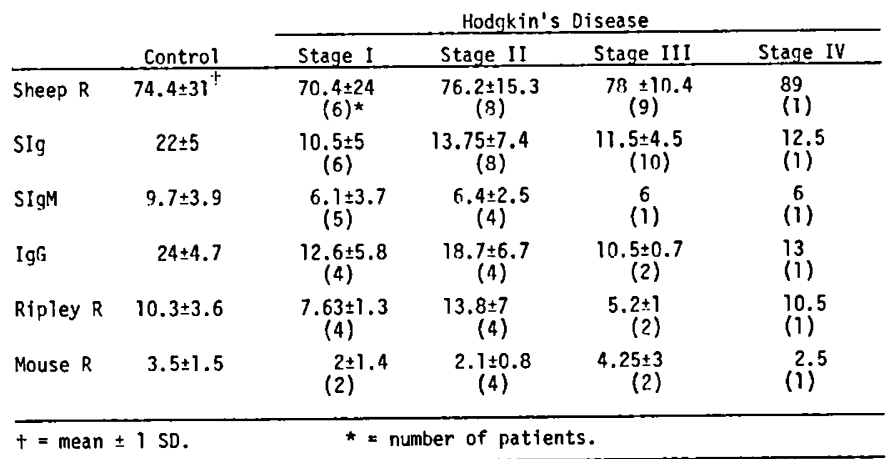

\section{Concomitant Analysis of Peripheral Blood and Spleen Lymphocyte Populations}

Concomitant analysis of peripheral blood and spleen iymphocyte populations in nine HD patients. In four additional patients, the spleen, bu the blood, was studfed. All spleen cell suspen
logically uninvolved sections of the spleen.

The finding of low percentages of $T$ cells in the blood in three cases $(23.5 \%, 45.5 \%$, and $62.5 \%)$ was not accompanied by a simultaneous decrease in the percentage of $T$ cells found in the spleen (61\%, 51\%, and $83 \%$, respectively). On the contrary, in eight of the thirteen spleens of HD patients examined, percentages of $\dot{T}$ cells higher than those reported for normal human spleens (Tables III and VI) were found (range 56-75\%). Low percentages of splenic T cells were observed in patients S.M., V.G., R.P. and L.F. In three of these four patients, disease involvement was observed in extra-iymphoid sites, namely bone (V.G. and L.F.) and lung (R.P.).

On the whole, low percentages of B lymphocytes $(7-17 \%)$ were found in HO patients who had low percentages of $T$ cells. The finding of low percentages of $B$ cells in the spleen paralleled the concomitant $B$ cell depletion of the blood (Table $V$ ). One striking finding was that in only five of eleven cases did the percentages of $T$ and $B$ lymphocytes account for the majority of splenic iymphoid cells.

\section{TABLE VI}

PERCENTAGE DISTRIBUTION OF T AND $B$ LYMPHOCYTES

IN PERIPHERA

\begin{tabular}{|c|c|c|c|c|c|c|c|c|}
\hline \multirow[b]{2}{*}{ Stage } & \multirow[b]{2}{*}{ Patient } & \multirow[b]{2}{*}{ Histology } & \multicolumn{2}{|c|}{$\mathrm{T}$} & \multicolumn{2}{|c|}{$B$ (SIg) } & \multicolumn{2}{|c|}{$B(\operatorname{Ig} M)$} \\
\hline & & & Blood & Spleen & Blood & Spleen & Blood & Spleen \\
\hline \multirow[t]{3}{*}{ IA } & G.E. & LP & 23.5 & 61 & 14 & - & - & - \\
\hline & N.M. & LP & - & 56 & - & 34 & - & 15 \\
\hline & S.M. & NS & 84.5 & 35 & 3.5 & 11 & 2.5 & 6 \\
\hline \multirow[t]{2}{*}{ IEB } & M.B. (lung)* & NS & 76 & 61 & 15 & 14 & 2 & 11 \\
\hline & J.v. & MC & 65.5 & 76 & 11.5 & 17 & 9.5 & 3 \\
\hline IIA & J.S. & NS & 45.5 & 51 & - & - & - & - \\
\hline IIEB & V.G. (bone)* & NS & 80 & 45 & 3.5 & 12 & 4 & 8 \\
\hline IIIA & G.z. & NS & - & 51 & - & 25 & - & - \\
\hline \multirow[t]{3}{*}{ IIIB } & A.S. & MC & 83.5 & 53 & 18 & 33 & 8 & 20 \\
\hline & C.o. & NS & 62.5 & 83 & 9 & 16 & 3 & 10 \\
\hline & J.A. & NS & - & 69 & - & 7 & - & - \\
\hline IIIEB & R.P. (lung)* & NS & 64.5 & 19 & 10 & 36 & 6 & 23 \\
\hline IVB & L.F. (bone)* & MC & - & 45 & - & 49 & 15 & 36 \\
\hline $\begin{array}{l}\text { Mean } \\
\pm I \text { SD } \\
\end{array}$ & & & $\begin{array}{r}65 \\
+20 \\
\end{array}$ & $\begin{array}{r}54.2 \\
+16.9 \\
\end{array}$ & $\begin{array}{r}10.4 \\
+5.2 \\
\end{array}$ & $\begin{array}{r}23 \\
+13.2 \\
\end{array}$ & $\begin{array}{r}6.5 \\
+4.4 \\
\end{array}$ & $\begin{array}{r}14.6 \\
+10.3 \\
\end{array}$ \\
\hline
\end{tabular}

* site of extra-lymphoid involvement by disease.

\section{DISCUSSION}

A number of explanations based on different ovservations have been used for the association of abnormal $T$ cell function with $H D$ in adult patients. Several of these different observations aré a : a) low numbers of peripheral blood jymphocytes (1) and $T$ lymphocytes $(2,3,7)$; b) the finding of functionally deficient populations of $T$ cells at all stages of $H D(5,6,7,21,22,26)$; $c$ ) the finding of autoantibodies against $T$ iymphocytes (15); and d) the presence of serum factors capable of inhibiting E-rosette formation $(12,23)$.

In our present series of studies of immunological function in children with HD $(8,26)$, we have been investigating the additional possibility that the known anomalies of lymphocyte number and function in the peripheral blood reflect a maldistribution of $T$ lymphocytes in the body rather than an absolute cell deficit. Evidence for a "maldistribution hypothesis" derives from: a) spleen $(8,20,22,26)$; b) finding of increased percentages of $T$ iymphocytes in spleens from $H D$ patients uninvolved by the disease $(8,24)$; and $c$ ) failure of imphocytes from splenectomized patients to respond to inhibition of E-rosette formation by HD serum $(12,25)$.

The present results show that in children with Ho there is nelther lymphopenia nor a diminished number of $T$ cells in the blood. Failure to observe de-
pressed E-rosette formation in these patients may be the result of technical differences between laboratories or may be related to the fact that our patients are children. In the majority of spleens studied (nine of thirteen), higher percentages of $T$ lymphocytes were present (range $51-83 \%$ ) in the HD cases than in the literature controls. This finding, together with our previous report of normal PHA response of splenic lymphocytes in the same children (26). supports the interpretation that a sequestration of the PHA responsive $T 1 \mathrm{ym}-$ phocytes has occurred in the spleen with the concomitant appearance in the peripheral blood of a non-responsive thymus-derived E-rosette population. Further evidence for this view derived from the finding that af ter splenectomy the pattern of the PHA response in the blood
main clinically free of the disease (9).

It was of interest to find that, of the three patients with low T cell numbers in the spleen, two had disease in extra-lymphoid sites. We interpret these findings tentatively to reflect migration of lymphocytes to the disease site.

More intriguing was the finding of a real deficit of $B$ lymphocytes both in spleen and blood. Low absolute counts of B lymphocytes have been reported also in the peripheral blood of adult patients $(5,75)$, but no simultaneous bloodspleen determinations have previously been reported.

These findings illustrate well the value of multicompartmental analys is in discriminating between "real" and "apparent" lymphocyte deficits or deficiencies. In the case of $\mathrm{HO}$, how the real $B$ cell deficit and the $T$ cell maldistribution relate to the pathogenesis of the disease remains unclear.

The knowledge that in $H D$ excessive amounts of ferric iron $(10)$ and of ferritin (11) are found in tissues and the recent observation of Moroz et al (23) demonstrating the presence of ferritin on the surface of $T$ lymphocytes in HD patients, raise the possibility that abnormalities of iymphocyte distribution in $\mathrm{HD}$ may be associated with anomalies of iron handling and distribution of iron binding proteins in tissues. We are presently further investigating this possibility.

\section{REFERENCES}

1. Aisenberg, A.C.: Lymphocytopenia in Hodgkin's disease. Blood 25: 1037 (1965).

2. Andersen, E.: Depletion of thymus dependent lymphocytes in Hodgkin's disease. Scand. J. Haematol. 12: 263 (1974).

3. Auiti, F. and Wigzell, H.: Function and distribution pattern of human TIymphocytes. II. Presence of T-lymphocytes in normal humans and in humans with varion.

4. Bentwich, Z., Douglas, S.D., Siegal, F.P. and Kunkel, H.G.: Human lymphocyte sheep erythrocyte rosette formation. Some characteristics of the interaction. Ciin. Immunol. Immunopath. 85: 351 (1973).

5. Bobrove, A., Fuks, Z., Strober, S. and Kaplan, H.S.: Quantitation of $T$ and B lymphocytes and celiular immune function in Hodgkin's disease. Cancer 36 $169(1975)$.

6. Case, D.C... Jr., Hansen, J.A., Corrales, E., Young, C.W., Dupont, B. Pinsky, C.M. and Good, R.A.: Comparison of multiple in vivo and in vitro parameters in untreated patients with Hodgkin's disease. Cancer 38: 1807 (1976).

7. Cohnen, G., Augener, W. and Brittinger, G.: Rosette-forming lymphocytes in Hodgkin's disease. New Engt. J. Med. 289: 863 (1973).

8. de Sousa, M., Yang, M., Lopes-Corrales, E., Tan, C., Hansen, J.A., Dupont, B. and Good, R.A.: Ecotaxis: the principle and its application to the study of Hodgkin's disease. Clin. Exp. Immunol. 27: 143, 1977.

9. de Sousa, M., Tan, C. and Hansen, J.A.: Changes in peripheral blood Iymphocyte function following splenectomy in children with Stage I Hodgkin's disease. In preparation.

10. Dumont, A.E., Ford, R.J. and Becker, F.F.: Siderosis of lymph nodes in patients with Hodgkin's disease. Cancer 38: 1274 (1976).

11. Eshhar, Z., Order, S.E. and Katz, D.H.: Ferritin, a Hodgkin's disease associated antigen. Proc. Natl. Acad. Sci. 기: 3956 (1974).

12. Fuks, Z., Strober, S. and Kaplan, H.S.: Interaction between serum factors and T lymphocytes in Hodgkin's disease. New Engl. J. Med. 295: 1273 (1976).

13. Gajl-Peczalska, K.J., Hansen, J.A., Bloomfield, C.D. and Good, R.A.: B ymphocytes in untreated patients with malignant lymphoma and Hodgkin's disease. J. Clin. Invest. 52: 3064 (1973).

14. Greaves, M., Janossy, G. and Doenhoff, M.: Selective triggering of human $T$ and $B$ imphocytes in vitro by polycional mitogens. J. Exp. Med. 140 1 (1974).

15. Grifont, $V .:$ Recent immunological findings in Hodgkin's disease. Tumori 59: $363(1973)$

16. Gupta, S.: Cell surface markers of human $T$ and B lymphocytes. New York State J. Med. 76: 24 (1976).

17. Gupta, S., Good, R.A. and Siegal, F.P.: Rosette formation with mouse erythrocytes. III. Studies in patients with primary immunodeficiency and lymphoproliferative disorders. Clin. Exp. Immunol. 26: 204 (1976).

18. Habeshaw, J.A. and Stuart, A.E.: $T$ and $B$ cells in human spleens. Lancet 1: 1164 (1974).

19. Kaplan, H.S.: Hodgkin's disease and other human malignant lymphomas: Advances and prospects - G.H.A. Clowes Memorial Lecture. Cancer Res. 36 3863 (1976).

20. Kaur, J., Catovsky, D., Spiers, A.S.D. and falton, D.A.G.: Increase of lymphocytes in the spieen of Hodgkin's disease. Lancet $\underline{i}: 834$ (1974).

21. Levy, R. and Kaplan, H.S.: Impaired lymphocyte function in untreated Hodgkin's disease. New Engl. J. Med. 290: 181 (1974). 
22. Matchett, K.M., Huang, A.T. and Kremer, W.B.: Impaired Iymphocyte transformation in Hodgkin's disease. J. Clin. Invest. 52: 1908 (1973).

23. Moroz, C., Lahat, N., Biniaminov, M. and Ramot, B.: Ferritin on the surface of lymphocytes in Hodgkin's disease patients. A possible blocking substance removed by levamisole. Clin. Exp. Immunol. 29: 30 (1977).

24. Payne, S.V., Jones, D.B., Haegert, D.G., Smith, J.C. and Wright, D.H.: $T$ and $B$ iymphocytes and Reed-Sternberg cells in Hodgk'n's disease iymph nodes and spleens. Clin. Exp. Immunol. 24: 280 (1976).

25. Siegal, F.P.: Inhibition of T-cell rosette formation by Hodgkin's-disease serum. New Engl. J. Med. 295: 1314 (1976).

26. Tan, C.T.C., de Sousa, M., Tan, R., Hansen, U.A. and Good, R.A.: Immunological parameters in childhood Hodgkin's disease. I. A study of lymphocyte transformation in vitro in response to stimulation by mitogens and antigens; with normal children controls. In preparation.

General legends for Figures 1, 2, and 3:

Stages:
- IA
O- IB
口. IIA
$\square-$ IIB
$\Delta$ - IIIA
$\Delta-$ IIIB
胡 - IVB

Shaded area represents control range (mean $\pm 1 \mathrm{SD}$ )

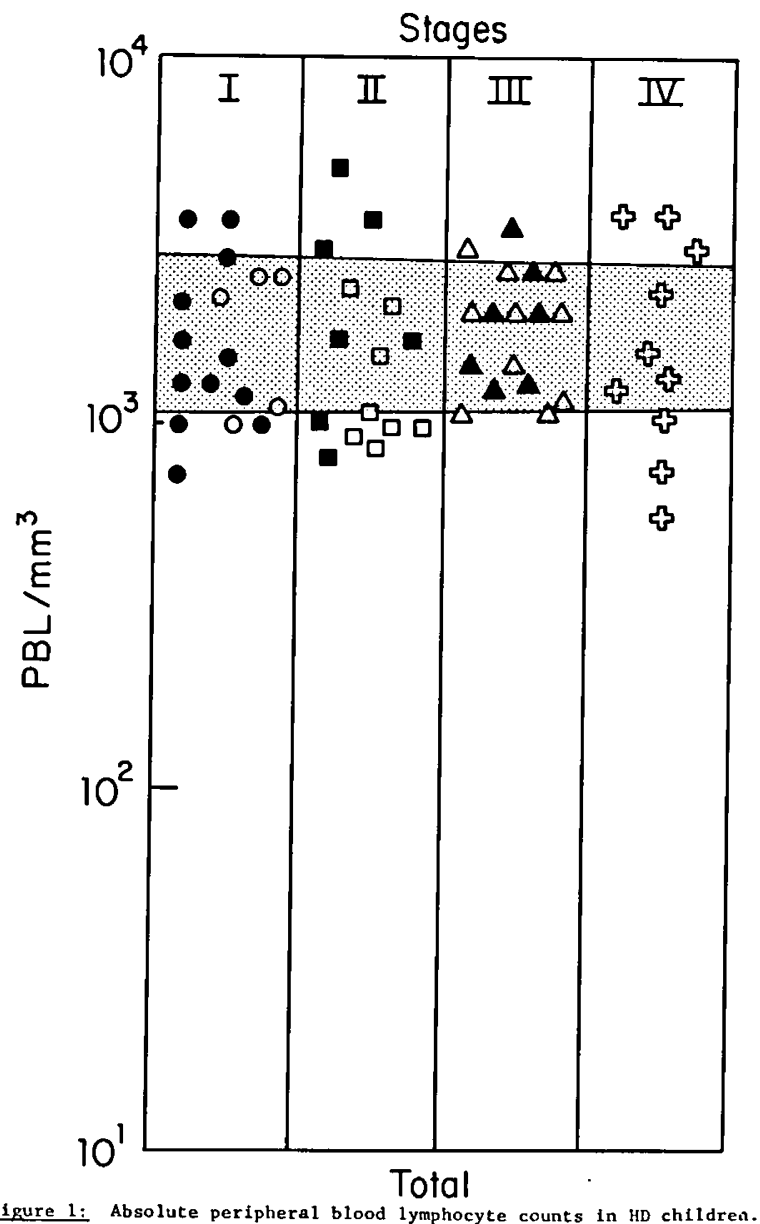

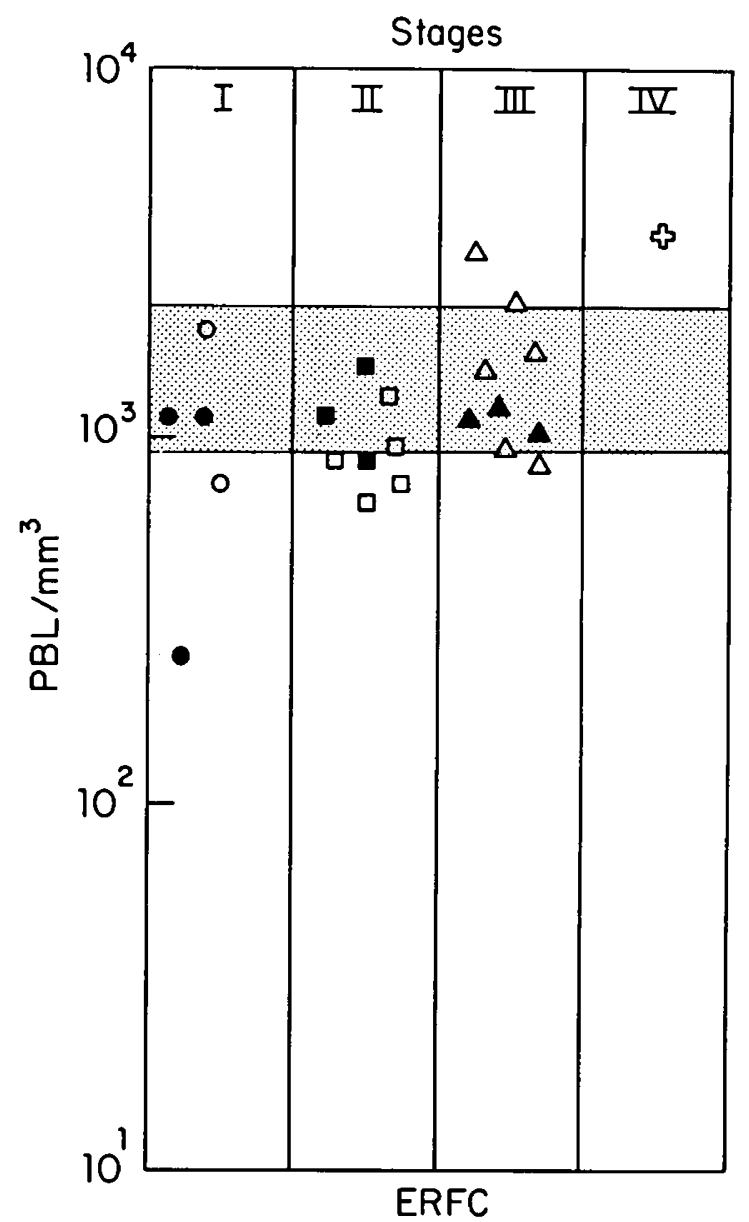

Figure 2: Absolute peripheral blood $T$ lymphocyte counts in HD children, determined by spontaneous rosette formation with sheep erythrocytes (ERFC). 


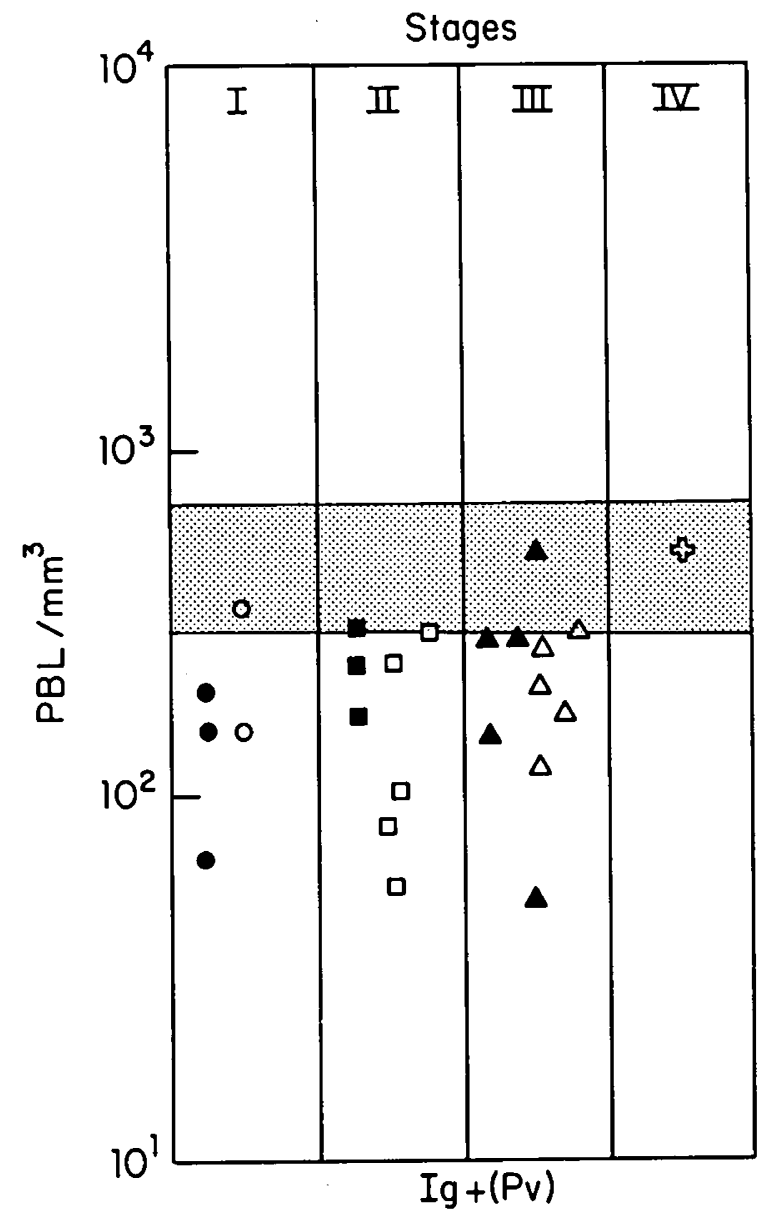

Figure 3: Absolute peripheral blood B lymphocyte counts in th chlldren, determined by the presence of surface

immunoglobulin ( $\mathrm{Pv}=$ polivalent ant I-IgG antiserum).

Copyright (c) 1978 International Pediatric Research Foundation, Inc. 